\title{
PENERAPAN METODE SIMULASI PADA MATERI PEMBELAJARAN PRESS CONFERENCE GUNA MENINGKATKAN SOFT SKILL DAN MUTU PEMBELAJARAN DI SMKN 3 BANDUNG TINGKAT 11 (AP4)
}

\author{
IMPLEMENTATION OF SIMULATION METHOD ON LEARNING MATERIAL PRESS \\ CONFERENCE TO IMPROVE SOFT SKILL AND LEARNING QUALITY AT SMKN 3 \\ BANDUNG LEVEL 11 (AP 4)
}

\author{
Tri Handayani \\ SMK Negeri 3 Bandung \\ E-mail: trihandayani13368@gmail.com
}

\begin{abstract}
ABSTRAK
Penelitian ini dilakukan untuk mengetahui bagaimanakah hasil dari metode simulasi yang digunakan dalam proses pembelajaran. Adapun judul dari PTK ini adalah Penerapan Metode Simulasi pada Materi Pembelajaran Press Conference Guna Meningkatkan Soft Skill dan Mutu Pembelajaran di SMKN 3 Bandung Program Studi Administrasi Perkantoran Tingkat 11 (AP 4). Pelaksanaan PTK dimulai dengan siklus pertama yang terdiri dari empat yaitu perencanaan, pelaksanaan, pengamatan dan refleksi, dari refleksi pada siklus 1, selanjutnya disusun siklus 2 yang merupakan perbaikan dari kekurangan-kekurangan pada siklus 1 dengan kompetensi dasar yang sama namun diberikan peningkatan pemahaman materi dari guru. Pada siklus 1 nilai tertinggi 84 nilai terendah 73 nilai rata-rata siswa sebesar 81,33 , Pada siklus 2 nilai tertinggi 85 nilai terendah 80 rata-rata siswa sebesar 83,33, jadi $85-73$ : 73 × $100 \%=16,44 \%$ terjadi peningkatan hasil belajar siswa sebesar $16,44 \%$. Dengan demikian metode simulasi pada materi press conference ini bisa dijadikan alternatif pembelajaran dalam meningkatkan keterampilan siswa dalam melaksanakan simulasi, Dari proses simulasi tersebut terjadi peningkatan hasil belajar sebesar $16,44 \%$
\end{abstract}

Kata Kunci: metode simulasi, materi press conference, peningkatan soft skill dan mutu pembelajaran

\section{ABSTRACT}

This research was conducted to find out how the results of the simulation method used in the learning process. The title of this PTK is Implementation of Simulation Method on Learning Material at SMKN 3 Bandung Administration Program of Office Level 11 (AP 4). The implementation of PTK starts with the first cycle consisting of planning, implementation, observation and reflection. Reflection cycle 1 is then cycled 2 which is an improvement of the deficiencies in cycle 1 with the same basic competencies but given the increased understanding of the material from the teacher. The observation result in cycle 2 shows the change of student to a better direction where the students look more confident, carry out the simulation with the press conference material in a structured and smoothly. Confidence in this student increases because has been directed by the teacher. The equipment is well prepared as well as the memorization of group members' dialogue. Through simulation of teaching and learning process more attract student attention so will grow creativity and soft skill and can improve the ability to communicate verbal, express appearance, correct deficiency. On cycle 1 st the highest value is 84 , the lowest value is 73 , the average value is 81.33. In cycle 2, the highest score is 85 , the lowest score 80 and the average value is 83.33. So 85$73 \times 100 \%=16.44 \%$ of the increase in student learning is $16.44 \%$. This the simulation method on press conference material is an alternative learning in improving the students'skills in carrying out the simulation so that from the simulation process there is a learning increase of $16.44 \%$.

Keywords: simulation method, learning material, soft skill and learning quality improvement

\section{PENDAHULUAN}

Pendidikan sebagai usaha sadar manusia untuk memanusiakan manusia ke arah yang lebih baik kurang berhasil atau dengan kata lain gagal. Salah satu penyebabnya adalah akibat dari pergeseran makna pendidikan ke arah pengajaran. Sekarang ini proses pembelajaran "kering" dengan transaksi pendidikan nilai (transformation of value), dan lebih menitikberatkan pada aspek pengetahuan (transformation of knowledge), atau dengan kata lain pendidikan kita lebih menekankan aspek teknis atau keterampilan keras (hard skills), kurang menekankan keterampilan lunak (soft skills).

Pada tahun 2011 HDI bangsa Indonesia 
berada pada ranking 114 dari 117 negara yang diteliti, turun dari 113 pada tiga tahun terakhir. Untuk itu perlu pengelolaan yang baik untuk meningkatkan kualitas sumber daya manusia yang ada sekarang ini. Salah satu bidang yang perlu ditingkatkan adalah penanganan sumber daya manusia melalui pendidikan. Dalam dunia kerja, $15 \%$ keberhasilan seseorang ditentukan oleh pengetahuan dan keterampilan teknis (hard skill) dan sisanya $85 \%$ ditentukan oleh keterampilan lunak (soft skill) dalam mengelola dirinya sendiri dan orang lain (Haryati, 2015).

Sejalan dengan hal ini, Baedowi, Direktur Jenderal PMPTK Depdiknas, sebagaimana dikutip Triatmanto (2010), menyatakan bahwa saat ini ada kecenderungan masyarakat maupun sekolah sekadar memacu siswa untuk memiliki kemampuan akademik tinggi tanpa diimbangi pembentukan karakter yang kuat dan cerdas. Upaya sekolah maupun orang tua agar murid atau anaknya mencapai nilai akademis tinggi sangat kuat, tapi mengabaikan hal-hal yang non akademis (Sudiana, 2012).

Ketika berbicara masalah pendidikan di Indonesia, secara pasti dihadapkan pada berbagai masalah pendidikan tersebut. Masalah pendidikan di Indonesia berasal dari berbagai segmen, mulai dari para pengambil kebijakan di tataran puncak, sampai pada permasalahan diakar rumput yaitu peserta didik sebagai peserta didik. Namun bila dilihat secara mikro permasalahan pendidikan yang terjadi saat ini berakar dari permasalahan dalam tingkat satuan pendidikan yang paling kecil yaitu sekolah. Sekolah belum bisa secara optimal melaksanakan tugasnya.

Kualitas pendidikan saat ini menggunakan prestasi belajar peserta didik sebagai ukuran untuk menentukan tingkat keberhasilannya. Hal tersebut menunjukkan berhasil tidaknya proses pendidikan dapat diamati berdasarkan tinggi rendahnya prestasi belajar siswa. Selain itu kurangya program yang bertujuan untuk peningkatan soft skills peserta didik, dimana kegiatan pendidikan di sekolah dan kegiatan pembelajaran oleh guru di kelas, belum secara terprogram dan terstruktur memasukkan aspek soft skills dalam kegiatan belajarmengajar. Sadar atau tidak, sesungguhnya sedikit saja metode pembelajaran diperbaiki, bisa saja menghasilkan hasil pembelajaran yang dahsyat (Elfindri et al., 2010:9).

Pengembangan soft skills dapat dilakukan melalui proses pembelajaran (intrakurikuler) dan kegiatan kemahasiswaan (ekstrakurikuler). Pengembangan soft skills melalui kegiatan belajar atau tatap muka di dalam kelas memerlukan kreativitas pendidik dengan tetap mengacu pada pencapaian kompetensi mata pelajaran dan tujuan pembelajaran (Sudiana, 2012).

Perkembangan dunia pendidikan sekarang ini sangatlah pesat, salah satu faktor yang menjadi pendukungnya adalah perkembangan media teknologi dan komunikasi. Permasalahan pendidikan selalu muncul bersamaan dengan berkembang dan meningkatnya kemampuan siswa, situasi dan kondisi lingkungan yang ada, pengaruh informasi dan kebudayaan, serta berkembangnya ilmu pengetahuan dan teknologi. Kondisi di lapangan saat ini menunjukkan bahwa masih diberlakukannya pendekatan konvensional yang tidak efektif dan menimbulkan pada kejenuhan siswa di dalam kelas, serta pendekatan ketrampilan proses dengan pembelajaran teoritis (Ismail SM, 2008:1).

Penggunaan metode yang tidak sesuai dengan tujuan pengajaran akan menjadi kendala dalam mencapai tujuan yang telah dirumuskan dalam kompetensi dasar. Cukup banyak bahan pelajaran yang terbuang percuma hanya karena penggunaan metode menurut kehendak guru dan mengabaikan kebutuhan siswa, fasilitas, serta situasi kelas (Djamarah \& Zein, 2010:87).

Salah satu metode dalam pembelajaran adalah metode simulasi. Metode ini dimaksudkan sebagai cara untuk menjelaskan sesuatu (bahan pelajaran) melalui perbuatan yang bersifat pura-pura atau melalui proses 
tingkah laku imitasi, atau bermain peran mengenai suatu tingkah laku yang dilakukan seolah-olah dalam keadaan yang sebenarnya (Sudjana, 2009: 89). Metode simulasi ini bertujuan untuk membentuk ketrampilan anak didik dalam bertindak di kehidupan sehari-harinya dan untuk menyiapkan anak didik ketika mereka telah terjun di masyarakat. Kegiatan belajar mengajar merupakan kegiatan utama dalam proses pendidikan di sekolah.

Dalam metode pembelajaran simulasi ranah yang diutamakan adalah ranah keterampilan dalam mempraktekan teori yang dipelajari, sehingga sesuai dengan tujuan pembelajaran, bukan hanya sebatas kemampuan dalam memahami konsep sehingga dalam proses pembelajaran siswa SMK harus dibiasakan untuk menghadapi kondisi yang akan dihadapi di dunia nyata. Metode yang mampu menciptakan kondisi nyatake dalam kondisiyangbukan sebenarnya adalah metode simulasi. Dengan menerapkan metode simulasi, diharapkan perserta didik akan memperoleh manfaat seperti, menyampaikan informasi, meyakinkan pendengar, menghibur pendengar, membuat suatu ide atau gagasan, menyentuh emosi pendengar ataupun dapat memperkenalkan diri dengan cara yang menarik.

Metode pembelajaran simulasi ini akan diterapkan dalam materi pembelajaran press conference, karena komunikasi merupakan bagian yang paling mendasar dalam kehidupan manusia. Berkomunikasi secara verbal baik lisan maupun tulisan akan memberikan manfaat berupa kemampuan bersosialisasi yang baik. Press conference merupakan cara yang ampuh untuk sebuah organisasi dalam menyampaikan informasi kepada eksternal publik karena berita atau informasi tersebut dapat segera disampaikan oleh pers kepada masyarakat luas. Tujuan utama dari pelaksanan press conference tersebut adalah menyampaikan informasi positif kepada publik dan menjalin hubungan yang baik antara organisasi dengan eksternal publik, khususnya media atau pers.

Berkaitan dengan hal tersebut setiap peserta didik perlu dibekali dengan kompetensi yang baik dan merupakan hal yang perlu dipersiapkan agar menjadi sumber daya manusia yang bermutu sesuai dengan tuntutan pekerjaan. Maka dari itu dengan menggunakan simulasi dengan materi press conference akan menekankan pada keterlibatan peserta didik dalam proses pembelajaran yang aktif. Tujuan utama dari pelaksanan press conference tersebut adalah menyampaikan informasi positif kepada publik dan menjalin hubungan yang baik antara organisasi dengan eksternal publik, khususnya media atau pers.

Rumusan Masalah: (1) Apakah dengan menggunakan metode Simulasi pada materi press conference respon siswa terhadap pembelajaran dapat meningkat; dan (2) Apakah dengan menggunakan metode simulasi press conference kemampuan soft skill siswa dapat meningkat. Berdasarkan rumusan masalah tersebut, maka tujuan dari penelitian ini adalah sebagai berikut: (1) Mengimplementasikan metode simulasi pada materi press conference guna meningkatkan respon siswa terhadap pembelajaran; dan (2) Dengan menggunakan metode simulasi pada materipress conference kemampuan soft skill siswa lebih meningkat.

\section{METODE PENELITIAN}

Dalam penelitian tindakan kelas ini yang menjadi objek penelitian adalah siswa SMK Negeri 3 Bandung kelas XI AP 4 Administrasi Perkantoran dengan jumlah siswa 34 orang. Prosedur Penelitian: Penelitian tindakan kelas ini terdiri dari 2 siklus (siklus 1 dan siklus 2) yang tepatnya dilakukan pada bulan Oktober 2015.

\section{Siklus 1}

Pelaksanaan PTK dimulai dengan siklus pertama yang terdiri dari empat yaitu perencanaan, pelaksanaan, pengamatan dan refleksi. Apabila sudah diketahui 
keberhasilan tindakan pada siklus pertama dan sesuai dengan yang diharapkan, maka siklus kedua sebaiknya tetap dilaksanakan untuk mengukuhkan atau menguatkan hasil yang sudah diperoleh pada siklus pertama. Berikut merupakan penjelasan kegiatan siklus 1

Perencanaan. Rencana merupakan kegiatan pokok pada tahap awal. Pada tahap perencanaan ini peneliti menyusun perangkat pembelajaran yang terdiri dari silabus, Rencana Pelaksanaan Pembelajaran (RPP), menyusun tes hasil belajar Ulangan Harian (UH), Pekerjaan Rumah (PR), dan membuat lembar pengamatan aktivitas guru dan siswa. Dengan perencanaan yang baik guru pelaksana PTK akan lebih mudah mengatasi kesulitan dengan lebih efektif.

Pelaksanaan. Jika semua perencanaan tindakan telah disiapkan, maka langkah selanjutnya adalah melaksanakan skenario tindakan yang telah direncanakan dalam situasi aktual. Kegiatan pembelajaran ini dilakukan secara berkelompok yang memerlukan kreatifitas tinggi yang menjadikan pembeda dari kelompok lain, dari segi materi pembahasan yang terbaru dan cara penyampaian atau aplikasi simulasi press conference. Kegiatan pelaksanaan tindakan dilaksanakan sesuai jadwal yang ditetapkan pada saat yang bersamaan kegiatan pelaksanaan ini juga diikuti dengan kegiatan observasi.

Pengamatan. Pengamatan dilakukan terhadap aktivitas, interaksi dan kemajuan belajar siswa selama pembelajaran berlangsung. Pengamatan dilakukan bersamaan dengan pelaksanaan tindakan. Pengamatan bertujuan untuk mengamati apakah ada hal-hal yang harus segera diperbaiki agar tindakan yang dilakukan mencapai tujuan yang diinginkan.

Refleksi. Kegiatan refleksi yaitu mengkaji, melihat, dan mempertimbangkan atas hasil atau dampak dari tindakan, kelemahan, dan kekurangan dari proses pembelajaran yang dilakukan diperbaiki dengan rencana selanjutnya.

\section{Siklus 2}

Perencanaan. Dari refleksi pada siklus 1, selanjutnya disusun siklus 2 yang tahapan prosesnya sama dengan siklus 1 namun pada siklus 2 ini merupakan perbaikan dari kekurangan-kekurangan pada siklus 1 dengan kompetensi dasar yang sama namun diberikan peningkatan pemahaman materi baik dari guru maupun kelompok lain sebagai acuan.

Pelaksanaan. Dari perencanaan siklus 2 yang telah disiapkan, selanjunya diimplementasikan di kelas dalam bentuk pembelajaran yang regular artinya tidak mengambil waktu khusus, dengan tahapan yang sama dan memberi masukan kepada peneliti tentang langkah-langkah yang mungkin diambil dalam pelaksanaan siklus 2.

Pengamatan. Pada siklus 2 pengamatan terhadap aktivitas tetap dilakukan, Pengamatan dilakukan bersamaan dengan pelaksanaan tindakan. Pengamatan bertujuan untuk mengamati apakah ada hal-hal yang harus atau segera diperbaiki agar tindakan yang dilakukan mencapai tujuan yang diinginkan. Setelah proses pengayaan baik dari guru dan simulasi kelompok lain, kelompok yang melakukan perbaikan bisa meningkatkan penampilan simulasinya.

Refleksi. Kegiatan refleksi pada siklus 2 yaitu tetap mengkaji, melihat, dan mempertimbangkan atas hasil atau dampak dari tindakan, kelemahan, dan kekurangan dari proses pembelajaran yang dilakukan apakah perlu diperbaiki dengan rencana selanjutnya. Instruksi pengajaran yang digunakan pada siklus 2 berbeda dengan instruksi pengajaran pada siklus 1 namun tetap dalam kompetensi dasar yang sama.

\section{HASIL PENELITIAN DAN PEMBAHASAN}

Berdasarkan proses perencanaan seluruh rangkaian proses telah dilaksanakan, dari 
mulai penyusunan RPP sampai dengan mempersiapkan peralatan dan perlengkapan yang diperlukan dan dilanjutkan dengan implementasi press conference. Saat pelaksanaan proses belajar mengajar telah dilaksanakan dengan baik karena sebelumnya, konsep dan kompetensi dasar telah disampaikan sehingga, rencana pembelajaran berlangsung dengan baik.

Selama peneliti melakukan implementasi penelitian ini, pengamatan terhadap berlangsungnya penelitian tetap dilaksanakan (observasi). Hasil pengamatan ditemukan permasalahan pada siklus 1 yaitu, 1) Penampil kelompok pertama masih banyak kekurangan dalam persiapan materi; 2) Penampil kelompok pertama tidak mempersiapkan peralatan yang dibutuhkan dengan baik; 3)
Penampil kelompok pertama masih banyak kekurangan dalam kepercayaan diri, dan 4) Beberapa dari anggota kelompok pertama masih terlihat tidak hafal dialog.

Hal-hal yang menjadi masalah tersebut selanjutnya dijadikan masukan dan diperbaiki pada siklus 2. Pada siklus ke 2 terlihat perubahan siswa ke arah yang lebih baik, dimana para siswa terlihat lebih percaya diri, melaksanakan simulasi dengan materi press conference dengan terstruktur dan lancar. Kepercayaan diri pada siswa ini meningkat karena telah diberikan pengarahan kembali oleh guru. Peralatan sudah dipersiapkan dengan baik begitu juga dengan hafalan dialog anggota kelompok. Sehingga setelah dilakukan refleksi maka diperoleh hasil nilai siswa yang meningkat.

\begin{tabular}{ccc}
\hline Siklus & Nilai Tertinggi & Nilai Terendah \\
\hline Siklus 1 & 84 & 73 \\
\hline Siklus 2 & 85 & 80 \\
\hline Peningkatan Hasil Belajar & $16,44 \%$ \\
\hline
\end{tabular}

Dari data pada siklus 1 terlihat: Terdapat 1 kelompok yang tidak mencapai standar nilai 75 , sehingga tidak lulus kompetensi, Nilai tertinggi 84 , Nilai terendah 73 , Rata - rata nilai kelas XI AP 4 pada siklus 1 sebesar 81,33. Dari data siklus 2 setelah dilakukan perbaikan terhadap kekurangan - kekurangan pada siklus 1 diperoleh hasil refleksi sebagai berikut: Tidak terdapat siswa yang tidak lulus standar nilai simulasi materi press conference (seluruh siswa memperoleh nilai $\geq 75$ ), Nilai tertinggi 85 , Nilai terendah 80 , Rata - rata nilai kelas XI AP 4 pada siklus 2 adalah 83,4

Dari data tersebut menunjukan bahwa, simulasi materi press conference ini bisa dijadikan alternative pembelajaran dalam meningkatkan keterampilan siswa dalam melaksanakan simulasi, hal ini dapat terlihat dari perubahan tingkah laku siswa setelah melaksanakan simulasi yakni: 1) Melalui simulasi tersebut proses belajar mengajar lebih menarik perhatian siswa sehingga menumbuhkan kreatifitas dan soft skill; 2) Bahan atau materi pembelajaran lebih mudah dicerna oleh siswa; 3) Meningkatkan kemampuan berkomunikasi secara verbal dan meningkatkan rasa percaya diri; 4) Melalui simulasi siswa dapat mengekspresikan penampilan, mengkoreksi, dan membandingkan, dengan kelompok lain, dan 5) Dari proses simulasi tersebut terjadi peningkatan hasil belajar sebesar 16,44\%.

\section{SIMPULAN}

Berdasarkan rumusan masalah, tujuan, pembahasan dan hasil penelitian dapat penulis simpulkan sebagai berikut: 1) Melalui pelaksanaan simulasi materi press conference pada siklus ke 2 terlihat perubahan. Siswa terlihat lebih percaya diri, melaksanakan simulasi dengan materi press conference; 2) Memberikan bekal kecakapan berfikir ilmiah dalam proses pembelajaran serta memberikan nilai tambah (value added) yang positif 
bagi siswa; 3) Membantu pengembangan kompetensi guru dalam menyelesaikan masalah pembelajaran mencakup kualitas isi, efisiensi, dan efektivitas pembelajaran, proses, dan hasil belajar siswa, dan 4) Memperoleh perbaikan mutu pendidikan atau pembelajaran secara berkelanjutan.

\section{Rekomendasi}

Berdasarkan uraian di atas, maka dapat dikemukakan rekomendasi berupa penerapan metode simulasi dalam materi pembelajaran press conference, dimana pendidik dapat lebih kreatif lagi dalam penyiapan sarana prasarana pendukung untuk memfasilitasi siswa dalam mendalami materi yang diberikan, sehingga nantinya pemberian materi tersebut dapat menimbulkan soft skills yang positif bagi peserta didik.

Selain itu dibutuhkan penelitian yang lebih mendalam mengenai manfaat lain dari metode pembelajaran simulasi bukan hanya dalam materi pembelajaran press conference, tetapi dalam materi pembelajaran lain maupun dalam bidang yang berbeda.

\section{DAFTAR RUJUKAN}

Djamarah, S. B., \& Zein, A. (2010). Strategi Belajar Mengajar. Jakarta: Rineka Cipta.

Elfindri, Rumengan, J., Wello, M. B., Tobing, P., Yanti, F., Zein, ... Indra, R. (2010). Soft Skills Untuk Pendidik. T.K: Baduose Media.

Haryati, S. (2015). Upaya Meningkatkan Soft Skill Mahasiswa Di Perguruan Tinggi. Seminar Ilmiah Semesteran Korpri Sub Unit Kopertis Wilayah Vi Jawa Tengah, 1(2), 66-75.

Ismail SM. (2008), trategi Pembelajaran Agama Isam Berbasis PAIKEM. Semarang: RaSAIL Media Group.

Sudiana, I. K. (2012). Upaya Pengembangan Soft Skills Melalui Implementasi Model Pembelajaran Kooperatif Untuk Peningkatan Aktivitas Dan Hasil Belajar Mahasiswa Pada Pembelajaran Kimia Dasar. Jurnal Pendidikan Indonesia, 1(2), 91-101.

Sudjana, N. (2009). Dasar-dasar Proses Belajar Mengajar. Bandung: Sinar Baru Algensindo. 